\title{
HEREDITARY PITUITARY TUMOR SYNDROMES: GENETIC AND CLINICAL ASPECTS
}

\author{
Berenice García-Guzmán ${ }^{1}$, Lesly Portocarrero-Ortiz ${ }^{1}$, A. Agustín Dorantes-Argandar², \\ AND MOISÉS MERCADO ${ }^{3 *}$ \\ ${ }^{1}$ Endocrinology Service, Instituto Nacional de Neurología y Neurocirugía, Mexico City; ${ }^{2}$ Neurosurgery \\ Service and ${ }^{3}$ Experimental Endocrinology Unit, Hospital de Especialidades, Centro Médico Nacional Siglo XXI, \\ Instituto Mexicano del Seguro Social, Mexico City, Mexico
}

\begin{abstract}
The pituitary gland is responsible for the synthesis and secretion of various hormones that play a key role in regulating endocrine function and homeostasis. Pituitary adenomas (PA) are benign epithelial tumors arising from the endocrine cells of the anterior pituitary gland. Clinically relevant PA are relatively common and they occur in $0.1 \%$ of the general population. They are mostly benign monoclonal neoplasms that arise from any of the five hormone-secreting cell types of the anterior pituitary gland. PA are categorized as either functioning or non-functioning, depending on whether or not they produce a hormonal hypersecretion syndrome. Both functioning and non-functioning adenomas can produce symptoms or signs resulting from compression of the optic chiasm or invasion of cavernous sinuses. Only $5 \%$ of PA occur within the context of hereditary syndromes with reasonably well-defined oncogenic mechanisms. The vast majority of PA are sporadic, and their etiopathogenesis remains largely unknown. Pituitary tumor oncogenesis involves several mechanisms that eventually lead to abnormal cell proliferation and dysregulated hormone production. Among these factors, we found inactivating mutations of tumor suppressor genes, activating mutation of oncogenes and the participation of hormonal signals coming from the hypothalamus, all resulting in cellcycle regulation abnormalities. In this review, we summarize the clinical and pathophysiological aspects of the different hereditary pituitary tumor syndromes. (REV INVEST CLIN. 2020;72(1):8-18)
\end{abstract}

Key words: Pituitary adenoma. Tumor suppressor gene. Oncogene. Multiple endocrine neoplasia. Carney complex.

\section{INTRODUCTION}

Pituitary adenomas (PA) are benign epithelial tumors arising from the endocrine cells of the anterior pituitary gland and comprise $10-25 \%$ of all intracranial neoplasms, third only to meningiomas and glioblastomas $^{1}$. The prevalence of PA among autopsy and radiological studies is $16.7 \%$ and $22.5 \%$, respective$\mathrm{Iy}^{2,3}$. The majority of these incidentally found lesions are microadenomas measuring $<10 \mathrm{~mm}$ in diameter $^{2}$. The age-adjusted incidence rate of PA is estimated to be 3.4 cases per 100,000 individuals per year ${ }^{2}$. PA are very rare in children, with a prevalence of $0.1 /$ million $^{4}$. PA are broadly classified as functioning and non-functioning lesions, depending on whether or not they produce a hormonal hypersecretion syndrome ${ }^{2,5}$. The most frequent functioning PA are prolactinomas, followed by growth hormone
*Corresponding author:

Moisés Mercado

E-mail: moises.mercado@endocrinologia.org.mx
Received for publication: 19-07-2019

Approved for publication: 27-08-2019

DOI: $10.24875 /$ RIC.19003186

0034-8376 / (C) 2019 Revista de Investigación Clínica. Published by Permanyer. This is an open access article under the CC BY-NC-ND license (http://creativecommons.org/licenses/by-nc-nd/4.0/). 
$(\mathrm{GH})$-secreting somatotropinomas (causing acromegaly/gigantism), adrenocorticotropic hormone (ACTH)-secreting corticotropinomas (causing Cushing disease), and the less common TSH-secreting thyrotropinomas (causing central hyperthyroidism) ${ }^{2}$. In community-based studies, prolactinomas and clinically-nonfunctioning PA account for $47 \%$ and $33 \%$ of all PA, respectively ${ }^{5-8}$. The prevalence of clinically diagnosed PA is between 78 and 94 cases per 100,000 inhabitants $^{5-8}$. Non-functioning PA are the most common type when considering only macroadenomas, whereas prolactinomas predominate when considering both micro- and macro-adenomas ${ }^{5-8}$.

More than $95 \%$ of PA occur sporadically, without a recognized familial or inherited cause $\mathrm{e}^{9,10}$. X-chromosome inactivation and microsatellite analysis indicate that PA are monoclonal neoplasms ${ }^{11}$. Sometimes somatic changes occurring only in tumoral pituitary tissue are recognized as recurrent events and include GNAS (encoding the alpha subunit of the guanine nucleotide-binding protein) mutations in patients with acromegaly ${ }^{12}$ and USP8 (encoding ubiquitin carboxylterminal hydrolase 8) mutations in Cushing's disease $^{13}$. While these somatic genetic changes may confer some peculiar clinical features, such as increased responsiveness to therapy with somatostatin analogs ${ }^{14,15}$, they cannot be readily identified a priori. Indeed, most somatic genetic changes seen in PA subtypes are of uncertain pathogenic significance. This will likely change as a greater number of driver mutations causing pituitary tumorigenesis are identified. In $5 \%$ of PA, a number of inheritable genetic conditions have been identified at the germline level (9-10). These genetic or genomic disorders may be limited to PA alone or may be associated with involvement of other organs in a syndromic endocrine neoplasia setting. Hereditary pituitary tumors can be classified as syndromic (multiple endocrine neoplasia type 1 [MEN1], MEN4, Carney complex [CNC], familial paraganglioma-pheochromocytoma-PA syndrome, and McCune-Albright syndrome [MAS]) and isolated or non-syndromic (Familial Isolated PA and X-linked acrogigantism $[\mathrm{XLAG}]^{9-10}$.

Several factors are thought to be involved in the pathogenesis of pituitary tumors; these include genetic mutations, epigenetic dysregulation of cell cycle regulators, local growth factors, and possibly hypothalamic dysregulation ${ }^{16-18}$. Two key mechanisms are involved in the PA tumorigenic process: gain of function or activating mutations of oncogenes and loss of function or inactivation of tumor suppressor genes (TSG), which can occur either independently or in combination ${ }^{9-10,16-18 .}$.

In contrast to oncogene activation, TSG inactivation usually requires the loss of both alleles, according to Knudson's "two-hit" hypothesis ${ }^{19}$. The first hit may be an inherited heterozygous germline mutation, a somatic mutation, or the loss of one allele of a particular TSG; as long as the other gene remains functional, the disease or trait is not expressed ${ }^{17-19}$. However, when the other allele is altered (the so-called second hit), usually by a partial chromosomal deletion or silenced by methylation of its promoter, the full phenotypic expression of the condition ensues ${ }^{17-19}$. Such partial chromosomal deletion may lead to loss of heterozygosity ( $\mathrm{LOH}$ ) of common polymorphisms around the TSG locus ${ }^{18}$. A recently described second hit mechanism involves the upregulation of a microRNA which then turns off the remaining TSG allele ${ }^{20}$. LOH has been described on chromosomes $9,11 \mathrm{q} 13$, and 13 in approximately $20 \%$ of cases of sporadic PA ${ }^{9,10}$.

In this review, we aim to discuss the genetic causes and clinical spectrum of familial pituitary tumors, focusing on germline and somatic mosaic mutations causing familial isolated pituitary adenomas (FIPA) and syndromic conditions, including MEN1, MEN4, CNC, MAS, familial paraganglioma/pheochromocytoma/PA, and DICER1 syndrome (Table 1 ).

\section{SYNDROMIC PITUITARY ADENOMAS}

\section{MEN1}

MEN1 is a high-penetrance, autosomal dominant condition characterized by the development of parathyroid, pituitary, and pancreatic tumors ${ }^{21,22}$. Other, less common components of MEN1 are carcinoid tumors, adrenocortical tumors, facial angiofibromas, lipomatous tumors, and collagenomas ${ }^{21,22}$. MEN1 was formally described clinically in 1953 by Underhall et al.,23 and its autosomal dominant inheritance pattern was first suspected by Werner in $1954^{24}$. It is a rare condition, with a $0.25 \%$ prevalence in autopsy studies, affecting 1 in 30,000 individuals ${ }^{21,22,25,26}$. The majority 
Table 1 . Germline and mosaic mutations causing hereditary pituitary tumor syndromes

\begin{tabular}{|c|c|c|c|c|c|}
\hline Syndrome & $\begin{array}{l}\text { Affected } \\
\text { gene }\end{array}$ & Function & $\begin{array}{l}\text { Chromosomal } \\
\text { locus }\end{array}$ & $\begin{array}{c}\text { Penetrance } \\
(\%)\end{array}$ & Clinical characteristics \\
\hline MEN 1 & MEN1 & $\begin{array}{l}\text { Tumor } \\
\text { suppressor }\end{array}$ & $11 q 13.1$ & $30-40 \%$ & $\begin{array}{l}\text { Hyperparathyroidism, } \\
\text { PAs (mostly prolactinomas } \\
\text { and GH-secreting), NET, } \\
\text { other neoplasms }\end{array}$ \\
\hline MEN 4 & CKDN1B & $\begin{array}{l}\text { Tumor } \\
\text { suppressor }\end{array}$ & $12 q 13.1$ & unknown & $\begin{array}{l}\text { MEN-1 like, usually with } \\
\text { GH-secreting pituitary } \\
\text { adenomas }\end{array}$ \\
\hline Carney Complex & PRKARIA & $\begin{array}{l}\text { Tumor } \\
\text { suppressor }\end{array}$ & $17 q 24.2$ & $10-15 \%$ & $\begin{array}{l}\text { Skin pigmentation; cardiac } \\
\text { and cutaneous myxomas; } \\
\text { thyroid, testis and } \\
\text { adrenal tumors, pituitary } \\
\text { hyperplasia, and PAs }\end{array}$ \\
\hline $\begin{array}{l}\text { Pheochromocytoma/ } \\
\text { paraganglioma/ } \\
\text { pituitary adenoma } \\
\text { syndrome }\end{array}$ & $\begin{array}{l}\text { SDHA } \\
\text { SDHB } \\
\text { SDHC } \\
\text { SDHD } \\
\text { MAX }\end{array}$ & Oncogene & $\begin{array}{c}5 p 15.33 \\
1 p 36.13 \\
1 q 23.3 \\
11 q 23.1 \\
14 q 23.3\end{array}$ & $\begin{array}{c}\quad<1 \% \\
<1 \% \\
<1 \% \\
<1 \% \\
\text { Unknown }\end{array}$ & $\begin{array}{l}\text { Familial pheochromocytomas } \\
\text { and paragangliomas } \\
\text { (PPGLs) }\end{array}$ \\
\hline DICER 1 Syndrome & DICER 1 & $\begin{array}{l}\text { RNA } \\
\text { interference }\end{array}$ & $14 q 32.12$ & $<1 \%$ & $\begin{array}{l}\text { Early onset pituitary } \\
\text { blastomas } \\
\text { (adrenocorticotropic } \\
\text { hormone secreting), } \\
\text { pleuropulmonary blastoma, } \\
\text { ovarian sex cord-stromal } \\
\text { tumors, cystic nephroma, } \\
\text { thyroid cancer }\end{array}$ \\
\hline FIPA & AIP & $\begin{array}{l}\text { Tumor } \\
\text { suppressor }\end{array}$ & $11 q 13.2$ & $15-30 \%$ & $\begin{array}{l}\text { Young-onset somatotroph } \\
\text { or mixed somatotroph- } \\
\text { lactotroph PAs and } \\
\text { prolactinomas. Responsible } \\
\text { for } 15-30 \% \text { of FIPA } \\
\text { kindreds and up to } 20 \% \\
\text { of young-onset PAs, } \\
\text { often resistant to } \\
\text { pharmacological therapy }\end{array}$ \\
\hline XLAG & GPR 101 & Oncogene & Xq26.3 & $100 \%$ & $\begin{array}{l}\text { Early-onset ( }<4 \text { years) } \\
\text { gigantism }\end{array}$ \\
\hline $\begin{array}{l}\text { McCune-Albright } \\
\text { syndrome }\end{array}$ & GNAS1 & Oncogene & $20 q 26.3$ & $20 \%$ & $\begin{array}{l}\text { Polyostotic fibrous dysplasia, } \\
\text { café-au-lait spots, and } \\
\text { precocious puberty } \\
\text { with } \mathrm{GH} \text { and/or PRL excess }\end{array}$ \\
\hline
\end{tabular}

MEN1: multiple endocrine neoplasia type 1; GEP NET: gastroenteropancreatic neuroendocrine tumor; MEN4: multiple endocrine neoplasia type 4; NFPA: non-functioning pituitary adenoma; PA: pituitary adenoma; FIPA: familial isolated pituitary adenoma.

of MEN1 cases (90\%) occur in a familial-hereditary setting, and only $10 \%$ occur sporadically $21,22,25,26$. MEN1 is the ultimate diagnosis in $1-18 \%$ of patients with primary hyperparathyroidism, $16-38 \%$ of patients with gastrinomas, and in $<3 \%$ of patients with pituitary tumors. The disease affects both females and males equally, and the age at presentation ranges between 5 and 81 years, with $95 \%$ of the patients developing the clinical manifestations by the fifth decade of life $21,22,25,26$.

Primary hyperparathyroidism is the most common clinical manifestation of MEN1 with a $95 \%$ penetrance ${ }^{25,26}$. Primary hyperparathyroidism occurring in the context of MEN1 has an earlier age of onset (2025 years) than that occurring in non-MEN1 patients 
(50-55 years) ${ }^{25,26}$. Pancreatic islet cell tumors have a prevalence of $30-80 \%$ and include gastrinomas, insulinomas, glucagonomas, VIPomas (vasoactive intestinal peptide-secreting tumors), and somatostatinomas. MEN1 patients with pancreatic islet cell tumors on average have an earlier age of onset compared to non-MEN1 patients with similar lesions ${ }^{25,26}$. Gastrinomas are the most common pancreatic islet cell tumors in MEN1 patients, accounting for over half of all pancreatic islet cell tumors seen in these subjects ${ }^{25,26}$. The majority of gastrinomas occurring in the context of MEN1 are malignant ${ }^{25,26}$. Insulinomas account for nearly $10-30 \%$ of all pancreatic islet cell tumors and can coexist with gastrinomas in $10 \%$ of MEN1 patients ${ }^{25,26}$. Glucagonomas are seen in $<3 \%$ of MEN1 patients. The clinical features of glucagonoma include diarrhea, weight loss, anemia, necrolytic migratory erythema, and stomatitis ${ }^{25,26}$. PA occur in $15-90 \%$ of MEN1 patients, and the majority of these are prolactinomas (60\%), followed by somatotropinomas (25\%), clinically non-functioning PA (CNFPA) (10\%), and corticotropinomas $(5 \%)^{26,27}$. Patients with PA occurring in the context of MEN1 are younger and more frequently harbor macroadenomas than those occurring sporadically ${ }^{26,27}$.

Approximately $80 \%$ of patients with MEN1 harbor mutations of the MEN1 gene ${ }^{21,22}$. Although a few MEN1 cases are due to mutations in genes coding for other cell cycle regulators such as p15, p18, and p21, in 15$20 \%$ of cases no mutations can be found ${ }^{21,22}$. The MEN1 susceptibility gene was initially linked to a locus on chromosome $11 \mathrm{q} 13$ in 1988 by Larsson et al. ${ }^{28}$, and the MEN1 gene was subsequently cloned in $1997^{29,30}$. The MEN1 gene has ten exons of which exons 2-10 encode a 61 aminoacid nuclear protein called, menin, whose functions are still being elucidated ${ }^{29,30}$. Menin appears to be located mostly in the nucleus, where it has multiple binding partners, including jun-D and members of the histone methyltransferase complex ${ }^{21,22}$. Menin potentially interacts with promoter regions of many genes, indicating its wide transcriptional regulatory role ${ }^{21,22}$. It has long been hypothesized that the tumor suppressive actions of menin are mediated through the regulation of histone methylation in promoters of p 27 and Hox genes and possibly other cyclindependent kinase (CDK) inhibitors ${ }^{31}$.

About $75 \%$ of MEN1 mutations are inactivating, consistent with what would be expected for a TSG $21,22,32$.
Somatic MEN1 mutations are commonly found in sporadic parathyroid $(20 \%)$ and pancreatic neuroendocrine tumors (NET) $(30 \%)^{21,22,32}$. These mutations are extremely rare in sporadic PA. $\mathrm{LOH}$ at $11 \mathrm{q} 13$ has been described in $30 \%$ of sporadic PA although MEN1 mRNA is not downregulated in these tumors ${ }^{21-23,33}$.

\section{MEN4}

Around $3 \%$ of patients with MEN1 have no identifiable menin mutations $22,32,34$. In some of these patients, abnormalities in genes encoding other CDKs have been identified $22,32,34$. These patients are classified as having MEN4 and the majority harbor germline, heterozygous, and non-sense mutations of $C D$ $K N 1 B$ (inhibitor $1 B$ ) that results in a truncated $\mathrm{p} 27$ protein $^{34-41}$. CDKN1B is a TSG located on chromosome $12 q 13$ in humans and encodes the CDK p27. $C D K N 1 B$ transcription is regulated by menin, which enhances the activity of its promoter through interaction with histone methyltransferases ${ }^{31}$. p2 7 levels are also regulated through mitogen-activated protein kinase and phosphatidylinositol-4,5-bisphosphonate 3-kinase catalytic subunit ${ }^{42}$. Loss-of-function mutations in CDKN1B lead to decreased cellular levels of p27 and/or to p27 functional defects ${ }^{42}$. Until 2019, only 29 MEN4 cases were reported ${ }^{34}$. Very recently, Frederiksen et al. described a large Danish family with 13 cases of multiple endocrine tumors, none of which harbored any abnormalities in menin, that segregated with a pathogenic $C D K N 1 B$ variant (c.121_122delTT, p.Leu41Asnfs*83) ${ }^{43}$. A comprehensive phenotype of MEN4 patients is not yet established due to the small number of patients identified so far. For the same reasons, the penetrance of MEN4, the frequency of familial and sporadic cases, and the phenotype-genotype correlations cannot be established yet. Primary hyperparathyroidism is present in all reported MEN4 patients ${ }^{34,42}$. Other MEN-1-like tumors identified are PA (corticotropinomas, somatotropinomas, and CNF$\mathrm{PA}$ ), NET, adrenocortical tumors, and meningiomas as well as uterine neoplasms ${ }^{34,42}$.

\section{$\mathrm{CNC}$}

$\mathrm{CNC}$ is a rare autosomal dominant condition with variable penetrance, characterized by various endocrine and non-endocrine abnormalities ${ }^{44,45}$. Approximately a total of 750 patients have been described to date $\mathrm{d}^{44,45}$. Cardiac myxomas that could be localized in 
any of the heart cavities are reported in $30 \%$ of the patients and may result in heart failure 44,45 . Myxomas have also been found in breast and $\operatorname{skin}^{44,45}$. Lentigines are among the most common cutaneous manifestations of $\mathrm{CNC}$ and occur in $70 \%$ of the patients. These skin lesions are small brown or black macules located around the lips, on eyelids, ears, and genital area ${ }^{44,45}$. Other skin findings that can be seen in half of the patients include Spitz nevi, blue nevi, schwannomas, and café-au-lait spots ${ }^{44,45}$. The most common endocrine abnormality is an ACTH-independent Cushing's syndrome, caused by micronodular pigmented adrenal hyperplasia, occurring in $25-30 \%$ of the patients ${ }^{44-46}$. Testicular, and to a lesser extent, thyroid nodules are relatively frequent ${ }^{44,45}$. Testicular nodules are usually Sertoli cell neoplasms, which may present as precocious puberty ${ }^{44,45}$. About $75 \%$ of patients with CNC exhibit asymptomatic elevations of both, $\mathrm{GH}$ and insulin-like growth factor 1 (IGF-1), usually associated with hyperplasia of the pituitary somatotroph; however, clinically evident acromegaly is rare ${ }^{48,49}$.

$\mathrm{CNC}$ is a genetically heterogeneous disease. Linkage analysis has identified three chromosomal loci to be associated with the disease: $17 q 22-24,2 p 16$, and $1 \mathrm{p} 31.1^{44-47}$. Over $70 \%$ of families with CNC harbor a germline-inactivating mutation of the alpha-1-regulatory subunit of the CAMP-dependent protein kinase $\mathrm{A}$ $(P R K A R 1 A)$ gene, located on chromosome $17 q 24^{44-}$ 47. Although the causative gene has not been identified, in $18 \%$ of CNC families, the molecular defect has been localized to $2 \mathrm{p} 16^{44,45,47}$. A single patient has recently been described with a duplication event in $1 \mathrm{p} 31.1^{44,45,47}$.

The PRKAR1A gene spans a $21-\mathrm{Kb}$ region and consists of 11 exons, comprising a coding region of 1143 bp that encodes a 381-amino acid protein of 42.9 $\mathrm{Kd}^{45,47}$. In its inactive state, PKA is a tetrameric enzyme consisting of two regulatory and two catalytic subunits. Four isoforms of the regulatory subunit have been described: R1alpha (encoded by PRKAR1A), R1beta, R2alpha, and R2beta, which interact forming homo- and hetero-dimers. Similarly, the catalytic subunit forms dimers giving rise to four different isoforms: Calpha, Cbeta, Cgamma, and PRKX. cAMP is bound by regulatory subunits (R2 [CAMP]4), thus dissociating the two catalytic subunits, rendering them free to phosphorylate and activate proteins such as cAMP response element-binding protein ( $p$-CREB) that result in the transcription of genes encoding proteins which promote cell proliferation and inhibit apoptosis (Fig. 1). Phosphorylated CREB also increases the transcription rate of Pit-1 that promotes the differentiation of thyrotrophs, somatotrophs, and lactotrophs ${ }^{44,45}$ and the transcription of genes encoding $\mathrm{TSH}, \mathrm{GH}$, and prolactin. Thus, the main role of the regulatory subunits is to limit the action of the catalytic subunits ${ }^{45-47}$. Inactivating mutations of PRKA$R 1 A$ result in an unrestricted action of the catalytic subunits and thus, promote cell proliferation and hormone production. Over 40 different mutations have been described, including point mutations, insertions, small deletions, and combined rearrangements of less than 15 bp $^{44,45,47}$. The majority of these mutations generate a direct or frameshift premature stop codon, which results in a truncated protein. A two base-pair deletion in exon 5 of the gene is the most frequently seen mutation in CNC patients ${ }^{44,45,47}$. This genetic defect is found de novo in approximately $30 \%$ of CNC cases. Truncating PRKAR1A mutations result in $\mathrm{mRNA}$ instability due to a nonsense-mediated decay mechanism $^{44,45,47}$. LOH at 17q22-24 and loss of the normal allele have been demonstrated in CNC tumors. PRKA$R 1 A$ somatic mutations have not been identified in pituitary adenoma (PA) but have rarely been described in sporadic thyroid tumors ${ }^{50}$.

\section{Pheochromocytoma/paraganglioma (PPGL)/PA syndrome}

Although the first description of coexisting PA and PPGL dates back to $1952^{51}$, it was not until 2012 that a causal link between genes predisposing to catecholamine-secreting tumors and a GH-secreting PA was established ${ }^{52}$. In this report, Xekouki et al. describe a hypertensive 40-year-old male patient with acromegaly due to a large $\mathrm{GH}$-secreting PA who also had bilateral pheochromocytomas and multiple paragangliomas ${ }^{52}$. Genetic testing revealed the presence of a succinate dehydrogenase-D gene (SDHD) germline, frameshift mutation leading to a premature stop codon, as well as LOH of the SDHD locus in the resected $\mathrm{PA}^{52}$. The same mutation was also found in two affected relatives, including a paternal uncle who had been operated many years before for bilateral neck masses occurring in the context of uncontrolled hypertension ${ }^{52}$. A total of 74 patients having both PPGL and PA have thus far been reported: about 22 (29.7\%) with identified mutations in predisposition 
Figure 1. Molecular pathophysiology of carney complex. Receptor activation results in guanosine triphosphate (GTP) binding to the alpha subunit of the Gs-protein, dissociating it from the beta/gamma complex. The GTP-bound alpha subunit activates adenylate cyclase, leading to increased cAMP generation. cAMP activates protein kinase A by binding to its regulatory subunit $(R)$, leaving the catalytic subunit (C) free for serine-threonine phosphorylation and activation of proteins such as cAMP response element-binding (CREB) protein. Inactivating mutations of the $R$ subunit decrease its binding to the $C$ subunit, which results in increased activation of CREB and other target proteins, leading to increased cellular proliferation, and inhibition of apoptosis.

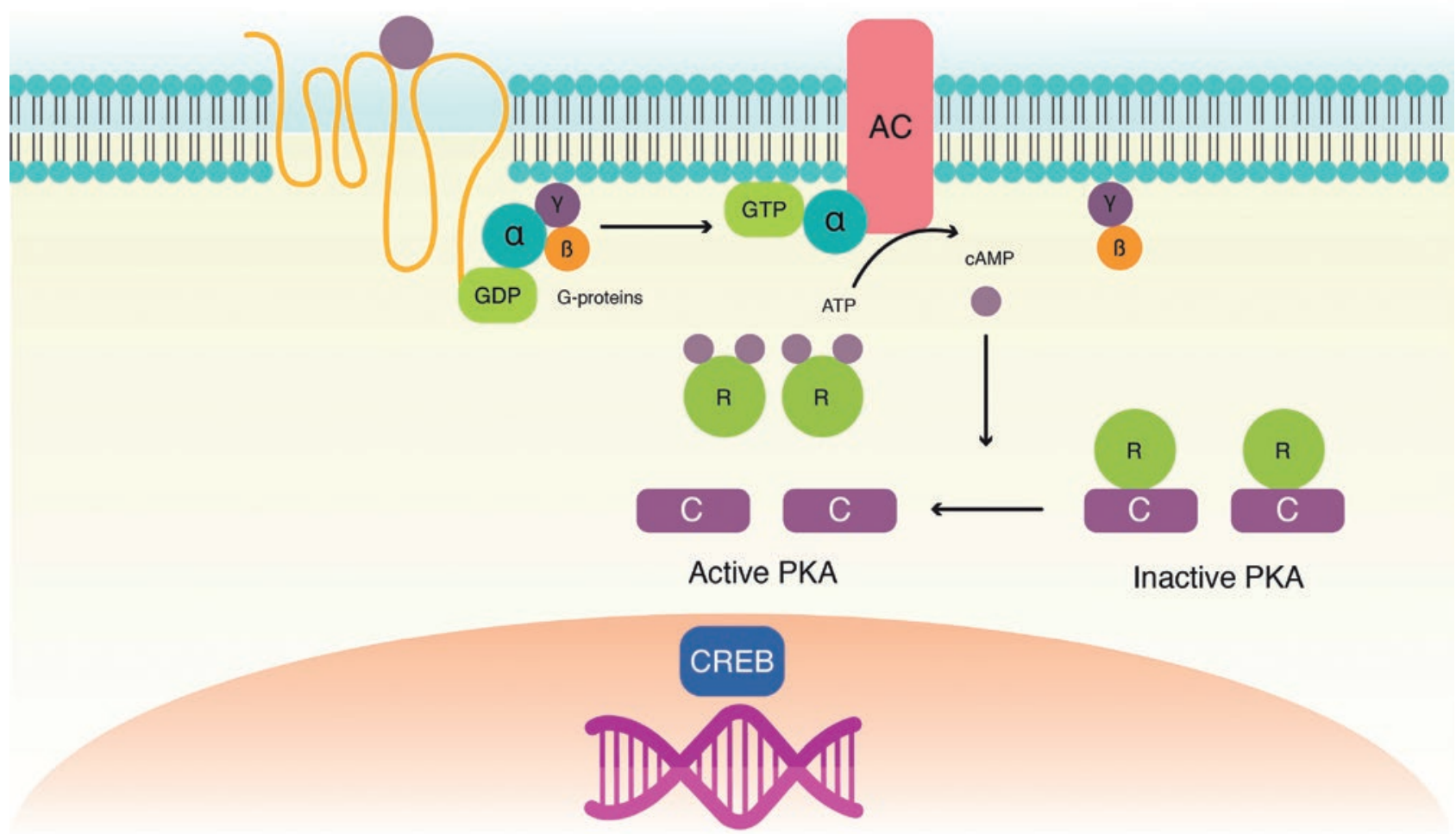

genes, 23 (31\%) with a personal or family history suggestive of a hereditary endocrine syndrome, and $29(39 \%)$ as isolated cases $^{10,53}$.

The SDH mitochondrial complex consists of four subunits ( $A, B, C$, and $D)$, which form the catalytic enzymatic core $(A$ and $B)$ and anchor the complex to the inner mitochondrial membrane (subunits $C$ and $D$ ), plus its associated assembly factor (SDHAF2) $)^{54-56}$. $\mathrm{SDH}$ is a key enzyme of the tricarboxylic acid and electron transport chain, catalyzing the conversion of succinate to fumarate ${ }^{54-56}$. Disruption of this enzymatic complex results in succinate accumulation which in turn inhibits prolyl hydroxylases; the inability to hydroxylate hypoxia-inducible factor $1 \mathrm{a}$ (HIF1a) leads to a pseudohypoxic state that promotes the transcription of HIF-responsive genes ${ }^{54-56}$.

\section{Pituitary blastoma and DICER1 mutations}

DICER1 syndrome, also known as pleuropulmonary blastoma (PPB)-familial tumor and dysplasia syndrome, is caused by a heterozygous germline mutation of the DICER 1 gene. The first case of pituitary blastoma was described in 2008 in a 13-month-old female child who presented with Cushing's disease and diabetes insipidus $^{57}$. The main manifestations are PPB, cystic nephroma, Sertoli-Leydig cell tumors, goiter, and more rarely, sarcomas, dysplasias, and pituitary blasto$\mathrm{ma}^{58,59}$. Characteristically, the presentation of the clinical components of this syndrome is age-specific $^{58,59}$. Despite its low penetrance $(<1 \%)$, pituitary blastoma is considered a pathognomonic feature of DICER1 syndrome. The median age of presentation is 
8 months (range 7-24 months) ${ }^{58,59}$. Symptoms of Cushing's disease and ophthalmoplegia are the most common presenting manifestations of pituitary blastoma ${ }^{58,59}$.

The DICER1 gene, located on $14 q 32.13$, encodes a small RNA processing endoribonuclease that cleaves precursor miRNAs into mature miRNAs, which in turn regulate mRNA expression ${ }^{60}$. The pathogenesis of pituitary blastoma encompasses the existence of a loss-of-function DICER 1 germline mutation plus the occurrence of a second somatic hit, which is crucial for tumor development in the embryonic pituitary ${ }^{61}$.

\section{ISOLATED PITUITARY ADENOMA}

\section{Familial isolated PA}

The term familial isolated PA alludes to a syndrome whereby two or more cases of a PA are found within a family, without any clinical or genetic features of MEN1 or $\mathrm{CNC}^{9,10,62}$. This autosomal dominant condition with incomplete penetrance is also known as isolated familial somatotropinoma since $\mathrm{GH}$-secreting adenomas are the most commonly found tumors. Since its description in 2006, several hundred families have been reported ${ }^{9,10,62}$.

The genetic defect in this syndrome was elucidated by linkage-disequilibrium analysis of a Finnish family with several members affected by $\mathrm{GH}$ and prolactinsecreting adenomas $9,10,63$. Whole-genome single nucleotide polymorphism genotyping of 11 affected individuals, found a haplotype involving 11q12-13 that perfectly segregated with the presence of acromegaly (LOD score 7.1) (63). The 11q12-13 locus encompasses over $60 \mathrm{Mb}$ and more than 29 genes $^{9,10}$. Comparative genomic hybridization using 172 probes found one gene to be associated in a statistically significant manner ${ }^{63}$. This gene is currently known as the AIP gene (AIP: aryl hydrocarbon receptor-interacting protein), but it was formerly known as ARA9 or XAP2 $2^{9,10,62-64 .}$

The AIP gene is located on chromosome $11 \mathrm{q} 13,3 \mathrm{Mb}$ distal to the MEN1 gene ${ }^{62,64}$. It contains six exons and encodes a 330 amino acid co-chaperone protein which is well-conserved throughout evolution ${ }^{62,64}$.
The amino-terminus of the AIP protein has an immunophilin-like domain, with significant homology to immunophilins FKBP12 and FKBP52 (Peptidyl-prolyl cistrans isomerase) ${ }^{62,64}$. However, it differs from other immunophilins by not sharing the ability to bind to immunosuppressant drugs such as cyclosporin or rapamycin ${ }^{62-64}$. The carboxy-terminus contains seven alpha helices that are crucial for protein-protein interactions: three 34 amino tetratricopeptide (TPR) domains, each with two helices, and a final seventh alpha helix62-64. The function of AIP is to stabilize the aryl hydrocarbon receptor/heat shock protein-90/dioxin complex in the cytoplasm, preventing it from being translocated into the nucleus ${ }^{62-64}$.

Over 100 different AIP mutations have been identified to date, including deletions, insertions, segmental duplications, nonsense, and missense mutations as well as deletions of whole exons or even the whole gene $^{62,65}$. Most of the pathogenic missense mutations directly affect the TPR domains or the C-terminal alpha-helix ${ }^{62,64,65}$. Two-thirds of the AIP mutations lead to protein truncations, which remove segments of the TPR domains and/or carboxy-terminal end, and therefore, lead to loss of function of the protein ${ }^{62,64,65}$. A common genetic "hotspot" for mutations in the AIP protein is the 304 residue (R304X and R304Q), which affects a CPG sequence and has been shown to be present in several independent families from different parts of the world ${ }^{65-68}$. Other potential hotspots include the 271 and the 81 loci (65-66). Inactivating AIP mutations are responsible for $20 \%$ of FIPA cases $^{62,65}$. Germline, heterozygous AIP mutations are also present in $5-10 \%$ of cases of sporadic $\mathrm{GH}$-secreting adenomas ${ }^{65-67}$. Acromegaly patients with AIP mutations are usually diagnosed before age 30 , usually harbor macroadenomas, frequently cosecrete prolactin and appear to be somewhat less responsive to treatment with somatostatin analogs ${ }^{65-67}$.

In AIP mutation-negative families, the pituitary tumors are also predominantly macroadenomas $(71 \%)^{65,66}$. The observed tumor types are also dominated by prolactin and $\mathrm{GH}$-secreting tumors, but CNFPA and rarely corticotroph adenomas have also been described ${ }^{65,66}$. The male-to-female ratio is $1: 1$, and the age of onset is more similar to sporadic PA patients ${ }^{65,66}$. Penetrance is probably slightly lower than in AIP-positive families ${ }^{65,66}$. 
A recent study has demonstrated that upregulation of AIP in the liver of transgenic mice increases the expression of the TSG ZAC1 (zinc finger regulator of apoptosis and cell cycle arrest) ${ }^{69,70}$. This is likely the mechanism by which AIP exerts its tumor suppressor effects in the pituitary. A recent study demonstrated that ZAC1 mRNA expression was significantly increased in $\mathrm{GH} 3$ cells transiently transfected with wildtype AIP compared to the empty vector and those transfected with mutant forms of AIP (C238Y, and $\mathrm{R} 304 \mathrm{X})^{69,70}$. New data from in vitro experiments on mouse embryonic fibroblast and PA cell lines demonstrate that AIP deficiency results in increased cAMP levels through defective Gai signaling ${ }^{71}$. This results in subsequent downregulation of phosphorylated extracellular signal-regulated kinases $1 / 2$ (p-ERK1/2) and $p-C R E B^{71}$. This new evidence suggests that defective Gai signaling is potentially a major contributor to the development of $\mathrm{GH}$-secreting PA in AIP mutation carriers $^{71}$.

\section{X-linked acrogigantism}

X-linked acrogigantism (XLAG) is a recently described condition characterized by severely increased linear growth developing at a very early age. This is very rare form of gigantism, first described in 2014 by Trivellin et al. ${ }^{72}$, results from microduplications of Xq23.6, encompassing a 500-bp sequence that includes the GPR101 gene ${ }^{73}$. Germline and to a lesser extent, mosaic mutations have been described, occurring both, in a familiar and sporadic setting ${ }^{72-77}$. Only 33 XLAG patients have been reported in the medical literature ${ }^{72-77}$. XLAG accounts for $8-10 \%$ of all gigantism cases $^{76,77}$. In contrast to gigantism due to AIP mutations whereby the majority of patients are male, in XLAG, there is a clear female predominance ${ }^{72-77}$. The principal manifestation is increased linear growth starting at a very early age ${ }^{72-77}$. Patients with XLAG have normal weight and height at birth and develop accelerated growth usually before the age of $5^{72-77}$. Other clinical features include acral enlargement, coarsened facial features, increased appetite, acanthosis nigricans, sleep apnea, and hyperhidrosis ${ }^{72-77}$. Biochemically, patients with this condition show very high basal and glucose-suppressed $\mathrm{GH}$ levels, as well as elevated age-adjusted IGF-1 concentrations; $85 \%$ have hyperprolactinemia ${ }^{72-77}$. Patients with XLAG usually have somatotroph hyperplasia and less commonly, well-defined adenomas ${ }^{73,76,78}$. Reticulin staining shows the characteristically distorted pattern of PA, and in some cases pseudofollicles and an eosinophilic colloid-like material are found. GH, PRL, and Pit-1 immunostaining are intense and diffuse ${ }^{73,76,78}$. Cam 5.2 immunostaining reveals the typical nuclear fibrous bodies of sparsely-granulated adenomas $^{63,64,73,76,78 \text {. }}$

The GPR101 gene encodes a Gs-protein-coupled orphan receptor that is normally expressed in the nucleus accumbens, medulla, and occipital cortex and abundantly expressed in pituitary tumors of XLAG patients ${ }^{79}$. The oncogenic processes resulting from GPR101 duplication are not completely understood; however, constitutive activation of this receptor could trigger the CAMP-PKA pathway and thus, cellular proliferation and autonomous $\mathrm{GH}$ hypersecretion of somatotrophs ${ }^{78}$. Since GPR101 appears to be involved in the regulation of GHRH release, hypersecretion of this hypothalamic hormone may contribute to somatotroph hyperplasia and increased $\mathrm{GH}$ secretion ${ }^{78}$.

\section{MOSAIC MUTATIONS}

\section{McCune-Albright}

McCune-Albright (MAS) was first described in 1937 by Donavan James McCune and Fuller Albright ${ }^{80,81}$. This is a rare and sporadic condition resulting from postzygotic mosaic mutations in the gene encoding the alpha subunit of the Gs protein (GNAS) ${ }^{82,83}$. Diagnosis of MAS is established on clinical grounds with patients having at least two features of the triad of polyostotic fibrous dysplasia (FD), café-au-lait skin pigmentation, and autonomous endocrine hyperfunction, including precocious puberty, thyrotoxicosis, pituitary gigantism, and Cushing syndrome as well as renal phosphate wasting ${ }^{49,84}$. The most common forms of autonomous endocrine hyperfunction in this syndrome are gonadotropin-independent precocious puberty, followed by thyrotoxicosis, pituitary gigantism, and Cushing syndrome. Café-au-lait spots are commonly the first manifestation and usually appear at birth or shortly thereafter. However, it is most often precocious puberty or FD that bring patients to medical attention ${ }^{49,84}$. FD is characterized by the lack of differentiation and proliferation of bone-forming stromal cells leading to replacement of normal bone and marrow by fibrous tissue ${ }^{49,84}$. FD most 
commonly behaves as a slowly growing mass lesion. Symptoms and signs vary depending on the type and location of FD and include craniofacial deformity, visual and hearing impairment, nasal congestion and/ or obstruction, paresthesia, and pain ${ }^{49,84}$. The most commonly involved areas are the proximal femur, the craniofacial bones, and the ribs ${ }^{49,84}$.

Pituitary disease in MAS consists of lactotroph and somatotroph cell hyperplasia or adenomas, resulting in prolactin and $\mathrm{GH}$ excess, respectively ${ }^{85,86}$. In up to $20 \%$ of patients with MAS, there is a lack of GH suppression on glucose loading ${ }^{85,86}$. The elevated $\mathrm{GH}$ and IGF-1 levels can result in acromegaly/gigantism and have been implicated in the sarcomatous transformation of osseous FD ${ }^{86,87}$. Clear-cut pituitary tumors can be found in only $50 \%$ of patients. Diagnosis of $\mathrm{GH}$ excess can be challenging in MAS patients. In children with MAS, rapid linear growth which could be a result of $\mathrm{GH}$ excess is often attributed to precocious puberty, which is a common finding in patients with $\mathrm{MAS}^{85,86}$. In addition, characteristic features of acromegaly such as coarsening of the face, frontal bossing, and prognathism not only develop insidiously but can also be wrongly attributed to FD of the skull which can result in dysmorphic features ${ }^{85,86}$.

GNAS is located on chromosome $20 q 13$ and encodes the ubiquitously expressed stimulatory Gs alpha subunit of the $G$ protein that has intrinsic GTPase activity ${ }^{86-88}$. Missense mutations at codons 201 or 227, result in loss of GTPase activity and lead to constitutive and permanent activation of adenylate cyclase and hence, of the CAMP-dependent PKA pathway ${ }^{82,83,87-89}$. MAS is due to early postzygotic GNAS mutations occurring at codon 201 resulting in somatic mosaicism, which underlies the complex phenotype of these patients $81,82,86,88$. A variable proportion of sporadic somatotropinomas harbor somatic mutations of either codon 201 or 227, that result in constitutive activation and thus, in increased cellular proliferation and unrestricted $\mathrm{GH}$ secretion ${ }^{12,14,89,90}$. The GNAS1 gene is a paternally imprinted gene in many tissues, including the pituitary gland; therefore, only mutations occurring on the maternal allele will result in an abnormal phenotype ${ }^{91}$. Whereas up to $40 \%$ of Caucasian patients with acromegaly harbor GNAS1 mutations ${ }^{12,14,89,90}$, this occurs in only $5-10 \%$ of Asian patients 92,93 and $15-20 \%$ of Latin-American Mestizo patients ${ }^{15,94}$. Acromegaly patients with GNAS1 mutations are likely to have a relatively milder phenotype with smaller, less invasive, usually densely-granulated adenomas that seem to respond better to surgery and treatment with somatostatin analogs $14,90,94$.

\section{Familial hyperprolactinemia}

A heterozygous mutation of the prolactin receptor has recently been described in members of a family with mild to moderate hyperprolactinemia and normal pituitary gland on MRI ${ }^{95}$. Some family members have fertility problems, while others are completely asymptomatic. In vitro expression studies have shown that this prolactin receptor mutant is not only uncapable of properly transducing a signal but also exerts a dominant-negative effect ${ }^{95}$.

\section{CONCLUSIONS}

Although $<5 \%$ of PA occur in the context of welldefined genetic syndromes, their molecular pathophysiology has helped us understand the potential mechanisms involved in the oncogenesis of sporadic PA in general. Some of these molecular abnormalities occurring in the germline in these hereditary syndromes can be found as somatic mutations in sporadic PA. PA found in patients with hereditary syndromes are usually larger, more invasive, and less responsive to pharmacological treatment. At present, genetic testing looking for abnormalities in GNAS, Menin or PRKARIA is recommended in patients with apparently sporadic PA who have a family history of pituitary tumors as well as in those who are relatively young at the time of diagnosis (less than age 30 ).

\section{REFERENCES}

1. Ostrom QT, Gittleman H, Farah P, Ondracek A, Chen Y, Wolinsky $Y$, et al. CBTRUS statistical report: primary brain and central nervous system tumors diagnosed in the United States in 2006 2010. Neuro Oncol. 2013;15 Suppl 2:1-56.

2. Molitch ME. Diagnosis and treatment of pituitary adenomas: a review. JAMA. 2017;317:516-24.

3. Ezzat S, Asa SL, Couldwell WT, Barr CE, Dodge WE, Vance ML, et al. The prevalence of pituitary adenomas: a systematic review. Cancer. 2004;101:613-9.

4. Chen J, Schmidt RE, Dahiya S. Pituitary adenoma in pediatric and adolescent populations. J Neuropathol Exp Neurol. 2019; 78:626-32

5. Fernandez A, Karavitaki N, Wass JA. Prevalence of pituitary adenomas: a community-based, cross-sectional study in Banbury (Oxfordshire, UK). Clin Endocrinol (Oxf) 2010;72:377-82. 
6. Raappana A, Koivukangas J, Ebeling T, Pirilä T. Incidence of pituitary adenomas in Northern Finland in 1992-2007. J Clin Endocrinol Metab. 2010;95:4268-75.

7. Tjörnstrand A, Gunnarsson K, Evert M, Holmberg E, Ragnarsson $\mathrm{O}$, Rosén $\mathrm{T}$, et al. The incidence rate of pituitary adenomas in Western Sweden for the period 2001-2011. Eur J Endocrinol. 2014:171:519-26.

8. Agustsson TT, Baldvinsdottir T, Jonasson JG, Olafsdottir E, Steinthorsdottir V, Sigurdsson G, et al. The epidemiology of pituitary adenomas in Iceland, 1955-2012: a nationwide population-based study. Eur J Endocrinol. 2015:173:655-64.

9. Marques P, Korbonits M. Genetic aspects of pituitary adenomas. Endocrinol Metab Clin North Am. 2017;46:335-74.

10. Pepe S, Korbonits M, lacovazzo D. Germline and mosaic mutations causing pituitary tumours: genetic and molecular aspects. J Endocrinol. 2019;240:R21-R45.

11. Herman V, Fagin J, Gonsky R, Kovacs K, Melmed S. Clonal origin of pituitary adenomas. J Clin Endocrinol Metab. 1990; $71: 1427-33$

12. Vallar L, Spada A, Giannattasio G. Altered gs and adenylate cyclase activity in human $\mathrm{GH}$-secreting pituitary adenomas. Nature. 1987:330:566-8.

13. Reincke M, Sbiera S, Hayakawa A, Theodoropoulou M, Osswald A, Beuschlein F, et al. Mutations in the deubiquitinase gene USP8 cause Cushing's disease. Nat Genet. 2015:47:31-8.

14. Landis CA, Harsh G, Lyons J, Davis RL, McCormick F, Bourne HR, et al. Clinical characteristics of acromegalic patients whose pituitary tumors contain mutant GS protein. J Clin Endocrinol Metab. 1990:71:1416-20

15. Mendoza V, Sosa E, Espinosa-de-Los-Monteros AL, Salcedo M, Guinto G, Cheng S, et al. GSPalpha mutations in mexican patients with acromegaly: potential impact on long term prognosis. Growth Horm IGF Res. 2005;15:28-32

16. Grossman AB. The molecular biology of pituitary tumors: a personal perspective. Pituitary. 2009;12:265-70.

17. Melmed S. Pathogenesis of pituitary tumors. Nat Rev Endocrinol. 2011;7:257-66.

18. Aflorei ED, Korbonits M. Epidemiology and etiopathogenesis of pituitary adenomas. J Neurooncol. 2014:117:379-94.

19. Knudson AG Jr. Mutation and cancer: statistical study of retinoblastoma. Proc Natl Acad Sci U S A. 1971;68:820-3.

20. Luzi E, Marini F, Giusti F, Galli G, Cavalli L, Brandi ML, et al. The negative feedback-loop between the oncomir mir-24-1 and menin modulates the men 1 tumorigenesis by mimicking the "Knudson's second hit". PLoS One. 2012;7:e39767.

21. Kamilaris CDC, Stratakis CA. Multiple endocrine neoplasia Type 1 (MEN1): an update and the significance of early genetic and clinical diagnosis. Front Endocrinol (Lausanne). 2019; 10:339.

22. Schernthaner-Reiter MH, Trivellin G, Stratakis CA. MEN1, MEN4, and carney complex: pathology and molecular genetics. Neuroendocrinology. 2016;103:18-31.

23. Underhall LO, Woolner LB, Black BM. Multiple endocrine adenomas; report of 8 cases in which the parathyroids, pituitary and pancreatic islets were evaluated. J Clin Endocrinol Metab. 1953;13:20-47.

24. Wermer P. Genetic aspects of adenomatosis of endocrine glands. Am J Med. 1954;16:363-71

25. Thakker RV. Multiple endocrine neoplasia Type 1 (MEN1). Best Pract Res Clin Endocrinol Metab. 2010;24:355-70.

26. Thakker RV, Newey PJ, Walls GV, Bilezikian J, Dralle H, Ebeling $P R$, et al. Clinical practice guidelines for multiple endocrine neoplasia Type 1 (MEN1). J Clin Endocrinol Metab. 2012; 97:2990-3011.

27. Vergès $B$, Boureille $F$, Goudet $P$, Murat $A$, Beckers $A$, Sassolas $G$, et al. Pituitary disease in MEN Type 1 (MEN1): data from theFrance-Belgium MEN1 multicsentre study. J Clin Endocrinol Metab. 2002;87:457-65

28. Larsson C, Skogseid B, Oberg K, Nakamura Y, Nordenskjöld M. Multiple endocrine neoplasia Type 1 gene maps to chromosome 11 and is lost in insulinoma. Nature. 1988;332:85-7.

29. Chandrasekharappa SC, Guru SC, Manickam P, Olufemi SE, Collins FS, Emmert-Buck MR, et al. Positional cloning of the gene for multiple endocrine neoplasia-Type 1. Science. 1997; 276:404-7.

30. Lemmens I, Van de Ven WJ, Kas K, Zhang CX, Giraud S, Wautot $V$, et al. Identification of the multiple endocrine neoplasia Type 1 (MEN1) gene. The European consortium on MEN1. Hum Mol Genet. 1997;6:1177-83

31. Karnik SK, Hughes CM, Gu X, Rozenblatt-Rosen O, McLean GW Xiong $\mathrm{Y}$, et al. Menin regulates pancreatic islet growth by pro- moting histone methylation and expression of genes encoding p27Kip1 and p18INK4c. Proc Natl Acad Sci U S A. 2005; 102:14659-64.

32. Lemos MC, Thakker RV. Multiple endocrine neoplasia Type 1 (MEN1): analysis of 1336 mutations reported in the first decade following identification of the gene. Hum Mutat. 2008; 29:22-32.

33. Satta MA, Korbonits M, Jacobs RA, Bolden-Dwinfour DA, Kaltsas $G A$, Vangeli V, et al. Expression of menin gene mRNA in pituitary tumours. Eur J Endocrinol. 1999;140:358-61.

34. Thakker RV. Multiple endocrine neoplasia Type 1 (MEN1) and Type 4 (MEN4). Mol Cell Endocrinol. 2014;386:2-15.

35. Pellegata NS, Quintanilla-Martinez L, Siggelkow H, Samson E, Bink K, Höfler H, et al. Germ-line mutations in p27Kip1 cause a multiple endocrine neoplasia syndrome in rats and humans. Proc Natl Acad Sci U S A. 2006;103:15558-63.

36. Georgitsi M, Raitila A, Karhu A, van der Luijt RB, Aalfs CM, Sane T, et al. Germline CDKN1B/p27Kip1 mutation in multiple endocrine neoplasia. J Clin Endocrinol Metab. 2007;92:3321-5

37. Agarwal SK, Mateo CM, Marx SJ. Rare germline mutations in cyclin-dependent kinase inhibitor genes in multiple endocrine neoplasia Type 1 and related states. J Clin Endocrinol Metab. 2009;94:1826-34.

38. Molatore S, Marinoni I, Lee M, Pulz E, Ambrosio MR, degli Uberti EC, et al. A novel germline CDKN1B mutation causing multiple endocrine tumors: clinical, genetic and functional characterization. Hum Mutat. 2010;31:E1825-35.

39. Malanga D, De Gisi S, Riccardi M, Scrima M, De Marco C, Robledo $\mathrm{M}$, et al. Functional characterization of a rare germline mutation in the gene encoding the cyclin-dependent kinase inhibitor p27Kip1 (CDKN1B) in a spanish patient with multiple endocrine neoplasia-like phenotype. Eur J Endocrinol. 2012; 166:551-60.

40. Occhi G, Regazzo D, Trivellin G, Boaretto F, Ciato D, Bobisse S, et al. A novel mutation in the upstream open reading frame of the CDKN1B gene causes a MEN4 phenotype. PLoS Genet. 2013;9:e1003350.

41. Tonelli F, Giudici F, Giusti F, Marini F, Cianferotti L, Nesi G, et al. A heterozygous frameshift mutation in exon 1 of CDKN1B gene in a patient affected by MEN4 syndrome. Eur J Endocrinol. 2014 171:K7-17.

42. Lee M, Pellegata NS. Multiple endocrine neoplasia Type 4. Front Horm Res. 2013;41:63-78.

43. Frederiksen A, Rossing M, Hermann P, Ejersted C, Thakker RV, Frost $\mathrm{M}$, et al. Clinical features of multiple endocrine neoplasia Type 4: novel pathogenic variant and review of published cases. J Clin Endocrinol Metab. 2019;104:3637-46.

44. Correa R, Salpea P, Stratakis CA. Carney complex: an update. Eur J Endocrinol. 2015;173:M85-97.

45. Kamilaris CDC, Faucz FR, Voutetakis A, Stratakis CA. Carney complex. Exp Clin Endocrinol Diabetes. 2019;127:156-64

46. Horvath A, Stratakis C. Primary pigmented nodular adrenocortical disease and Cushing's syndrome. Arq Bras Endocrinol Metabol. 2007;51:1238-44.

47. Forlino A, Vetro A, Garavelli L, Ciccone R, London E, Stratakis CA, et al. PRKACB and carney complex. N Engl J Med. 2014; 370:1065-7.

48. Pack SD, Kirschner LS, Pak E, Zhuang Z, Carney JA, Stratakis CA, et al. Genetic and histologic studies of somatomammotropic pituitary tumors in patients with the "complex of spotty skin pigmentation, myxomas, endocrine overactivity and schwannomas" (Carney complex). J Clin Endocrinol Metab. 2000; 85:3860-5.

49. Horvath A, Stratakis CA. Clinical and molecular genetics of acromegaly: MEN1, carney complex, mcCune-albright syndrome, familial acromegaly and genetic defects in sporadic tumors. Rev Endocr Metab Disord. 2008;9:1-11.

50. Sandrini F, Matyakhina L, Sarlis NJ, Kirschner LS, Farmakidis C, Gimm O, et al. Regulatory subunit Type I-alpha of protein kinase A (PRKAR1A): a tumor-suppressor gene for sporadic thyroid cancer. Genes Chromosomes Cancer. 2002;35:182-92.

51. Iversen K. Acromegaly associated with phaeochromocytoma. Acta Med Scand. 1952:142:1-5.

52. Xekouki P, Pacak K, Almeida M, Wassif CA, Rustin P, Nesterova $M$, et al. Succinate dehydrogenase (SDH) D subunit (SDHD) inactivation in a growth-hormone-producing pituitary tumor: a new association for SDH? J Clin Endocrinol Metab. 2012 97:E357-66.

53. Xekouki P, Szarek E, Bullova P, Giubellino A, Quezado M, Mastroyannis SA, et al. Pituitary adenoma with paraganglioma/ pheochromocytoma (3PAs) and succinate dehydrogenase de- 
fects in humans and mice. J Clin Endocrinol Metab. 2015; 100:E710-9.

54. Selak MA, Armour SM, MacKenzie ED, Boulahbel H, Watson DG, Mansfield KD, et al. Succinate links TCA cycle dysfunction to oncogenesis by inhibiting HIF-alpha prolyl hydroxylase. Cancer Cell. 2005;7:77-85

55. Gimenez-Roqueplo AP, Dahia PL, Robledo M. An update on the genetics of paraganglioma, pheochromocytoma, and associated hereditary syndromes. Horm Metab Res. 2012; 44:328-33.

56. Huang Y, Wang LA, Xie Q, Pang J, Wang L, Yi Y, et al. Germline SDHB and SDHD mutations in pheochromocytoma and paraganglioma patients. Endocr Connect. 2018;7:1217-25.

57. Scheithauer BW, Kovacs K, Horvath E, Kim DS, Osamura RY Ketterling RP, et al. Pituitary blastoma. Acta Neuropathol. 2008;116:657-66

58. Foulkes WD, Bahubeshi A, Hamel N, Pasini B, Asioli S, Baynam $\mathrm{G}$, et al. Extending the phenotypes associated with DICER1 mutations. Hum Mutat. 2011;32:1381-4.

59. Scheithauer BW, Horvath E, Abel TW, Robital Y, Park SH, Osamura RY, et al. Pituitary blastoma: a unique embryonal tumor. Pituitary. 2012;15:365-73.

60. Krol J, Loedige I, Filipowicz W. The widespread regulation of microRNA biogenesis, function and decay. Nat Rev Genet. 2010;11:597-610.

61. Sahakitrungruang T, Srichomthong C, Pornkunwilai S, Amornfa J, Shuangshoti S, Kulawonganunchai S, et al. Germline and somatic DICER1 mutations in a pituitary blastoma causing infantile-onset Cushing's disease. J Clin Endocrinol Metab. 2014; 99:E1487-92.

62. Beckers A, Aaltonen LA, Daly AF, Karhu A. Familial isolated pituitary adenomas (FIPA) and the pituitary adenoma predisposition due to mutations in the aryl hydrocarbon receptor interacting protein (AIP) gene. Endocr Rev. 2013;34:239-77.

63. Vierimaa $O$, Georgitsi $M$, Lehtonen $R$, Vahteristo $P$, Kokko A Raitila $A$, et al. Pituitary adenoma predisposition caused by germline mutations in the AIP gene. Science. 2006;312: 1228-30.

64. Trivellin G, Korbonits M. AIP and its interacting partners. J Endocrinol. 2011;210:137-55

65. Hernández-Ramírez LC, Gabrovska P, Dénes J, Stals K, Trivellin $G$, Tilley D, et al. Landscape of familial isolated and young-onset pituitary adenomas: prospective diagnosis in AIP mutation carriers. J Clin Endocrinol Metab. 2015;100:E1242-54.

66. Cazabat L, Bouligand J, Salenave $S$, Bernier M, Gaillard $S$, Parker F, et al. Germline AIP mutations in apparently sporadic pituitary adenomas: prevalence in a prospective singlecenter cohort of 443 patients. J Clin Endocrinol Metab. 2012; 97:E663-70.

67. Ramírez-Rentería C, Hernández-Ramírez LC, Portocarrero-Ortiz L, Vargas G, Melgar V, Espinosa E, et al. AIP mutations in young patients with acromegaly and the tampico giant: the Mexican experience. Endocrine 2016:53:402-11.

68. Chahal HS, Stals K, Unterländer M, Balding DJ, Thomas MG, Kumar AV, et al. AIP mutation in pituitary adenomas in the 18th century and today. N Engl J Med. 2011:364:43-50.

69. Chahal HS, Trivellin G, Leontiou CA, Alband N, Fowkes RC, Tahir $A$, et al. Somatostatin analogs modulate AIP in somatotroph adenomas: the role of the ZAC1 pathway. J Clin Endocrinol Metab. 2012;97:E1411-20.

70. Ibáñez-Costa A, Korbonits M. AIP and the somatostatin system in pituitary tumours. J Endocrinol. 2017;235:R101-16

71. Tuominen I, Heliövaara E, Raitila A, Rautiainen MR, Mehine M, Katainen R, et al. AIP inactivation leads to pituitary tumorigenesis through defective goi-cAMP signaling. Oncogene. 2015; 34:1174-84

72. Trivellin G, Daly AF, Faucz FR, Yuan B, Rostomyan L, Larco DO, et al. Gigantism and acromegaly due to xq26 microduplications and GPR101 mutation. N Engl J Med. 2014;371:2363-74.

73. Sargent J. Genetics: X-linked acrogigantism genetic characterization of a newly described paediatric growth disorder. Nat Rev Endocrinol. 2015;11:64.

74. Beckers A, Lodish MB, Trivellin G, Rostomyan L, Lee M, Faucz FR, et al. X-linked acrogigantism syndrome: clinical profile and therapeutic responses. Endocr Relat Cancer. 2015;22:353-67.
75. Daly AF, Yuan B, Fina F, Caberg JH, Trivellin G, Rostomyan L, et al. Somatic mosaicism underlies $X$-linked acrogigantism syndrome in sporadic male subjects. Endocr Relat Cancer. 2016 23:221-33.

76. lacovazzo D, Caswell R, Bunce B, Jose S, Yuan B, HernándezRamírez LC, et al. Germline or somatic GPR101 duplication leads to $\mathrm{X}$-linked acrogigantism: a clinico-pathological and genetic study. Acta Neuropathol Commun. 2016;4:56.

77. Rostomyan L, Daly AF, Petrossians P, Nachev E, Lila AR, Lecoq $\mathrm{AL}$, et al. Clinical and genetic characterization of pituitary gigantism: an international collaborative study in 208 patients. Endocr Relat Cancer. 2015;22:745-57.

78. Hou ZS, Tao YX. Mutations in GPR101 as a potential cause of $X$-linked acrogigantism and acromegaly. Prog Mol Biol Transl Sci. 2019;161:47-67.

79. Trivellin G, Bjelobaba I, Daly AF, Larco DO, Palmeira L, Faucz FR, et al. Characterization of GPR101 transcript structure and expression patterns. J Mol Endocrinol. 2016:57:97-111.

80. Albright F, Butler AM, Hampton AO, Smith P. Syndrome characterized by osteitis fibrosa disseminatta, areas of pigmentation and endocrine dysfunction with precocious puberty. N Engl J Med. 1937:216:727-46.

81. McCune DJ. Osteitis fibrosa cística: the case of a 9-year old girl who also exhibits precocious puberty, multiple pigmentation of the skin and hyperthyroidism. Am J Dis Child. 1936:62:743-4.

82. Weinstein LS, Shenker A, Gejman PV, Merino MJ, Friedman E, Spiegel AM, et al. Activating mutations of the stimulatory $G$ protein in the McCune-Albright syndrome. N Engl J Med. 1991; 325:1688-95.

83. Schwindinger WF, Francomano CA, Levine MA. Identification of a mutation in the gene encoding the alpha subunit of the stimulatory $\mathrm{G}$ protein of adenylyl cyclase in McCune-Albright syndrome. Proc Natl Acad Sci U S A. 1992;89:5152-6.

84. Salpea P, Stratakis CA. Carney complex and McCune Albright syndrome: an overview of clinical manifestations and human molecular genetics. Mol Cell Endocrinol. 2014;386:85-91.

85. Salenave S, Boyce AM, Collins MT, Chanson P. Acromegaly and mcCune-albright syndrome. J Clin Endocrinol Metab. 2014; 99:1955-69.

86. Dumitrescu CD, Collins MT. McCune-Albright syndrome. Orphanet J Rare Dis. 2008;3:12

87. Ringel MD, Schwindinger WF, Levine MA. Clinical implications of genetic defects in $\mathrm{G}$ proteins. The molecular basis of McCuneAlbright syndrome and Albright hereditary osteodystrophy. Medicine (Baltimore). 1996;75:171-84

88. Weinstein LS, Chen M, Liu J. Gs(alpha) mutations and imprinting defects in human disease. Ann N Y Acad Sci. 2002;968:173-97.

89. Landis CA, Masters SB, Spada A, Pace AM, Bourne HR, Vallar L, et al. GTPase inhibiting mutations activate the alpha chain of GS and stimulate adenylyl cyclase in human pituitary tumours. Nature. 1989;340:692-6.

90. Spada A, Arosio M, Bochicchio D, Bazzoni N, Vallar L, Bassett $\mathrm{M}$, et al. Clinical, biochemical, and morphological correlates in patients bearing growth hormone-secreting pituitary tumors with or without constitutively active adenylyl cyclase. J Clin Endocrinol Metab. 1990;71:1421-6

91. Hayward BE, Barlier A, Korbonits M, Grossman AB, Jacquet $P$, Enjalbert $A$, et al. Imprinting of the G(s)alpha gene GNAS1 in the pathogenesis of acromegaly. J Clin Invest. 2001;107: R31-6.

92. Hosoi E, Yokogoshi Y, Hosoi E, Horie H, Sano T, Yamada S, et al. Analysis of the gs alpha gene in growth hormone-secreting pituitary adenomas by the polymerase chain reaction-direct sequencing method using paraffin-embedded tissues. Acta Endocrinol (Copenh). 1993;129:301-6

93. Kim HJ, Kim MS, Park YJ, Kim SW, Park DJ, Park KS, et al. Prevalence of GS alpha mutations in Korean patients with pituitary adenomas. J Endocrinol. 2001;168:221-6.

94. Taboada GF, Tabet AL, Naves LA, de Carvalho DP, Gadelha MR. Prevalence of GSP oncogene in somatotropinomas and clinically non-functioning pituitary adenomas: our experience. Pituitary. 2009;12:165-9.

95. Newey PJ, Gorvin CM, Cleland SJ, Willberg CB, Bridge M, Azharuddin $\mathrm{M}$, et al. Mutant prolactin receptor and familial hyperprolactinemia. N Engl J Med. 2013;369:2012-20. 